International Research Journal of Management, IT \& Social Sciences
Available online at https://sloap.org/journals/index.php/irjmis/
Vol. 8 No. 6, November 2021, pages: 630-638
$\begin{aligned} & \text { ISSN: 2395-7492 } \\ & \text { https://doi.org/10.21744/irjmis.v8n6.1961 }\end{aligned}$

\title{
Implementation Motivation, Work Discipline in Work Productivity of Employees in the Hospital
}

Cokorde Istri Bintari Pemayun ${ }^{a}$ Ida Ayu Oka Martini ${ }^{\text {b }}$

\section{Article history:}

Submitted: 09 August 2021

Revised: 18 September 2021

Accepted: 27 October 2021

\section{Keywords:}

motivation;

work discipline;

work productivity;

\begin{abstract}
The hospital is one of the health service units for the community that functions health services, the hospital must pay attention to employee motivation so that good work discipline is realized, thereby creating work harmony that will later have an impact on productivity. The research objectives are to find out 1) The Effect of Motivation on Work Discipline at Udayana University Hospital; 2) The Effect of Motivation on Employee Productivity at Udayana University Hospital; 3) The Effect of Work Motivation and Discipline on Employee Productivity at Udayana University Hospital. This research uses quantitative methods with SEM PLS analysis techniques. This study shows the results of 1) The significant positive effect of motivation on employee discipline of 0.573 with a t-statistic value of $6.615 ; 2$ ) The significant positive effect of motivation on productivity is 0.307 with a t-statistic value of $3.730 ; 3$ ) The significant positive effect of employee discipline on productivity is 0.621 with a t-statistic value of 8.875 .
\end{abstract}

International research journal of management, IT and social sciences (C) 2021. This is an open access article under the CC BY-NC-ND license (https://creativecommons.org/licenses/by-nc-nd/4.0/).

Corresponding author:

Cokorde Istri Bintari Pemayun,

Undiknas Graduate School, Denpasar, Indonesia.

Email address: cokbintarii@gmail.com

\footnotetext{
Undiknas Graduate School, Denpasar, Indonesia ${ }^{\mathrm{b}}$ Undiknas Graduate School, Denpasar, Indonesia 


\section{Introduction}

The hospital is one of the health service units for the community in the field of health services, the hospital must pay attention to employee motivation so that good work discipline is realized, thus creating work harmony so that it can provide an increase in productivity (Putra, 2013). At the Hospital in improving the knowledge and skills of its employees often conduct training or training according to their competence, the work system is carried out based on shifts, namely morning, afternoon, and night shifts. However, the work productivity of hospital employees has not shown good productivity, this can be seen from the number of complaints from patients who visit the hospital (Uchino et al., 2014; Paré et al., 2006).

The NGO Indonesia Corruption Watch (ICW) examined the level of service, especially on the friendliness of services so that it became a patient complaint that was reported www.lifestyle.kompas.com states that the level of government and private hospital services is indifferent or less friendly to patients or the poor, such as the poor service of nurses in providing services to patients, few doctor visits for inpatients, and the service of pharmacists and laboratory officers are relatively slow or slow so that The patient has to wait a long time (Farida \& Christian, 2016; George et al., 2005). The results of the study presented by Ade stated that patient complaints to the hospital were of poor toilet quality, slow administration, and relatively expensive drug prices.

The results of research by Nurcaya (2007), on the analysis of the quality of hospital services in Indonesia province Bali, produced a study where the gap analysis on service quality showed that there was a gap between the quality of service provided by the hospital and what the patient expected (Bangun, 2012). The phenomenon of patients in hospitals experiencing complaints about the quality of service that has not been maximized is still considered necessary to get attention for researchers to improve the quality of service for each of these patients (Stoeber et al., 2013; Lam \& Gurland, 2008).

Of the several problems experienced by the hospital against patient complaints, this shows that the work productivity of employees in hospitals has not been maximized (Armstrong, 2010; Simon et al., 2000; Nnoaham et al., 2011). Based on the above phenomena and from the research results which show inconsistencies, the researchers are interested in conducting a study entitled "Motivation, Work Discipline and Employee Productivity at Udayana University Hospital (Dwivedula \& Bredillet, 2010; Arshadi, 2010).

The purpose of this study was to 1) analyze the magnitude of the influence of motivation on the work discipline of Udayana University Hospital employees; 2) analyze the magnitude of the influence of motivation on the productivity of Udayana University Hospital employees; 3) analyze the influence of motivation and work discipline on the productivity of Udayana University Hospital employees; and 4) analyze the influence of motivation on employee productivity through work discipline at Udayana University Hospital (Hu \& Liu, 2020).

\section{Literature review}

Motivation

Flippo in Hasibuan (2011), suggests motivation is the ability of superiors or leaders to their subordinates to achieve organizational or company goals jointly between employees and the company so that what is a common goal can be achieved. While Miftah (2012), states that motivation is a willingness that arises from someone to carry out activities to achieve their goals. From the two opinions above, in general, the motivational goal proposed by Rawung (2013), is motivation to encourage someone to their desire to do something in the hope of being able to achieve these goals and get results following their expectations.

Meanwhile, Hasibuan (2011), has ten motivational goals, including: improving employee morale and satisfaction; employee work productivity; employee absenteeism discipline; employee loyalty, creativity, and participation; employee welfare level; efficient use of tools and raw materials; maintaining the stability of the company's employees; streamlining the procurement of employees; able to build a good working atmosphere and relationship; and employees are responsible for their duties.

\section{Work discipline}

Nitisemito (2006), discipline is an attitude of obedience to changes imposed by the company, whether written or not. Arisandy (2004), states discipline as a form of the attitude of a person or employee voluntarily to comply with all regulations and decisions imposed by the company. While Rivai (2009), work discipline is communication as a

Pemayun, C. I. B., \& Martini, I. A. O. (2021). Implementation motivation, work discipline in work productivity of employees in the hospital. International Research Journal of Management, IT and Social Sciences, 8(6), 630-638. https://doi.org/10.21744/irjmis.v8n6.1961 
medium between leaders and employees in increasing awareness and willingness to comply with or fulfill all company regulations. Anggorowati (2012), states that work discipline is the implementation of management to encourage all members of the organization to meet the demands of various provisions.

The work discipline indicators presented by Harlie (2012), are:

a) Arrive on time

b) Adhere to working hours

c) Have work skills in their field of work

d) Have a good attitude

e) Creative and innovative at work.

\section{Work productivity}

The concept of mental attitude to make today's life better than tomorrow is part of productivity. Productive mental attitudes such as motivational, disciplined, creative, innovative, dynamic, professional, and fighting-spirited attitudes are following the statement put forward by Sedarmayanti \& Rahadian (2018); Göbel \& Zwick (2013). The opinion expressed by Ardana et al (2012) productivity is a comparison between the results achieved with the overall power or production factors used. The indicators of work productivity proposed by Triasmoro (2012), include: workability; trying to improve the results achieved; spirit at work; self-development, goals, and efficiency.

\section{Framework}

The research concept is a logical relationship from the theoretical basis and empirical studies that have been described in the previous section. Based on the problem formulation and framework of thinking in this study, the independent variables are Leadership (X1) and Motivation (X2), Competence (Y1), and performance (Y2). The following is a conceptual framework for the research (Widana et al., 2019).

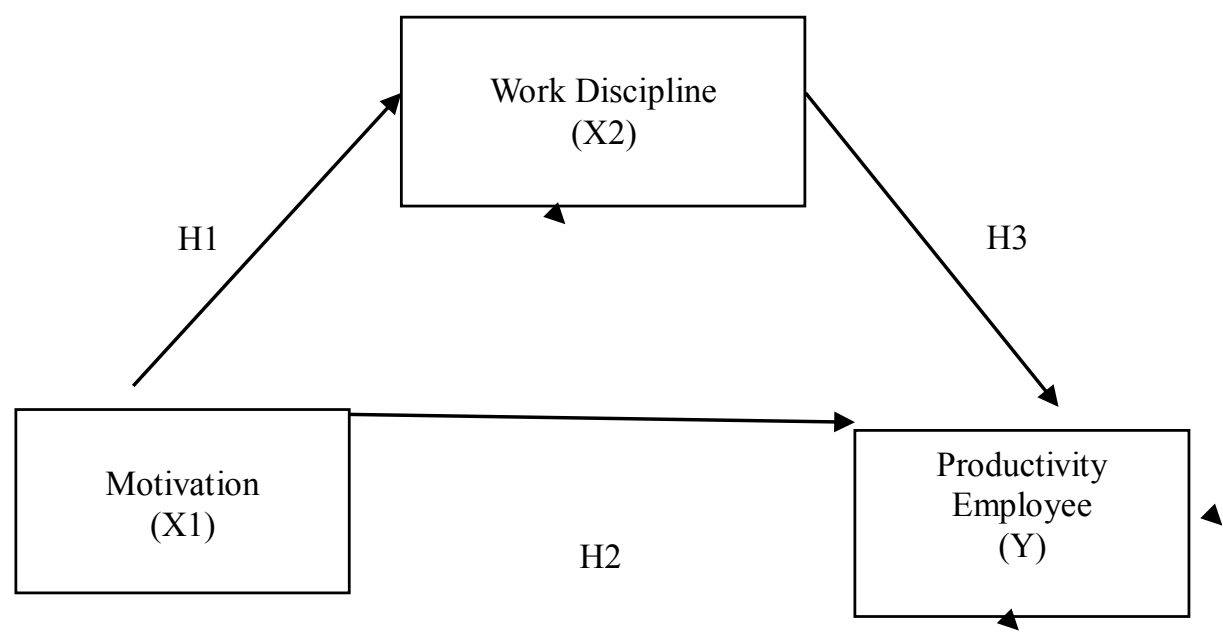

Figure 1. Research concept framework

\section{Research hypothesis}

H1: motivation effect Work Discipline in Hospital.

H2: motivation effect Employee Productivity In Hospital.

H3: motivation and Work Discipline effect Employee Productivity In Hospitals. 


\section{Materials and Methods}

The approach used in this study uses an objective or quantitative approach, with the PLS-SEM analysis technique. The total population in this study was 230 employees while the sample used was 92 respondents. The sampling technique used is probability sampling (Ghozali, 2006). Method of sampling (sampling) proportionate sampling or sampling proportionally on each employee. While the determination of respondents using random sampling (random sampling) with a lottery on the list of employees.

\section{Results and Discussions}

Evaluation of the outer model or measurement model

Table 1

Outer Loading

\begin{tabular}{|c|c|c|c|}
\hline Variables/indicators & Motivation & $\begin{array}{l}\text { Employee } \\
\text { Discipline }\end{array}$ & Productivity \\
\hline \multicolumn{4}{|l|}{ 1. Motivation } \\
\hline a. $\operatorname{mot} 1$ & 0.835 & & \\
\hline b. $\operatorname{mot} 2$ & 0.869 & & \\
\hline c. $\operatorname{mot} 3$ & 0.916 & & \\
\hline d. $\operatorname{mot} 4$ & 0.883 & & \\
\hline e. $\operatorname{mot} 5$ & 0.782 & & \\
\hline \multicolumn{4}{|l|}{ 2. Employee Discipline } \\
\hline a. dis 1 & & 0.790 & \\
\hline b. dis 2 & & 0.869 & \\
\hline c. $\operatorname{dis} 3$ & & 0.843 & \\
\hline d. dis4 & & 0.890 & \\
\hline e. dis5 & & 0.837 & \\
\hline \multicolumn{4}{|l|}{ 3. Productivity } \\
\hline a. prod1 & & & 0.898 \\
\hline b. prod 2 & & & 0.831 \\
\hline c. prod3 & & & 0.808 \\
\hline d. prod4 & & & 0.868 \\
\hline
\end{tabular}

Source: data processed by researchers, 2019

The processing results are as shown in the table above which shows that all indicators in each variable have an outer loadings value of more than 0.5 . The results of the outer loadings of all indicators on each of these variables are valid indicators for measuring variables.

Discriminant validity

Table 2

Discriminant validity

\begin{tabular}{clccccc}
\hline \multicolumn{2}{c}{ AVE } & \multicolumn{3}{c}{ Correlation } \\
\hline No & \multicolumn{1}{c}{ Variable } & AVE & AVE . root & Productivity & Employee Discipline & Motivation \\
\hline 1 & Productivity & 0.726 & 0.797 & 1 & & \\
2 & Employee Discipline & 0.737 & 0.847 & 0.797 & 1 & 1 \\
3 & Motivation & 0.717 & 0.852 & 0.663 & 0.573 & 1 \\
\hline
\end{tabular}

Source: data processed by researchers, 2019

Pemayun, C. I. B., \& Martini, I. A. O. (2021). Implementation motivation, work discipline in work productivity of employees in the hospital. International Research Journal of Management, IT and Social Sciences, 8(6), 630-638. https://doi.org/10.21744/irjmis.v8n6.1961 
Data in Table 2 can be explained that from the results of the three variables having an AVE value above 0.50 and all variables having an AVE root value higher than the correlation coefficient between one variable and another, it can be said that the data has good discriminant validity.

Composite reliability

Table 3

Composite reliability

\begin{tabular}{|c|c|c|}
\hline No & Variable & Composite Reliability \\
\hline 1 & Motivation & 0.933 \\
\hline 2 & Employee Discipline & 0.927 \\
\hline 3 & Productivity & 0.914 \\
\hline
\end{tabular}

Source: data processed by researchers, 2019

Table 3 shows that the composite reliability value of all constructs, which is above 0.60 , has met the reliable criteria. Overall evaluation results, both convergent. discriminant validity, composite reliability, which have been described above, it can be concluded that the indicators as a measure of the latent variable are valid and reliable measures.

Structural model testing (inner model)

Table 4

R-Squares . Value

\begin{tabular}{clc}
\hline No & \multicolumn{1}{c}{ Dependent Variable } & R Square \\
\hline 1 & Employee Discipline & 0.328 \\
2 & Productivity & 0.699 \\
\hline
\end{tabular}

Source: data processed by researchers, 2019

Variable R-square value discipline employees of 0.328 in Table 4.4 can be interpreted that $32.8 \%$ of the variability of the employee discipline construct is explained by the motivation variable, while $67.2 \%$ of the employee discipline variable is explained by variables outside the model. Likewise, the productivity variable has an R-square value of 0.699 or it is interpreted that $69.9 \%$ of the variability is explained by employee motivation and discipline, while $30.1 \%$ of the productivity variable is explained by variables outside the model.

Besides with use of R-square, the goodness of fit model was also measured using Q-Square predictive relevance for structural models, measuring how well the observed values are generated by the model and also the estimated parameters. Q-square value > 0 indicates the model has predictive relevance; On the other hand, if the value of QSquare 0 indicates that the model lacks predictive relevance. The Q-Square calculation is done by the formula:

$$
\mathrm{Q}^{2}=1-(1-R 12)(1-R 22) \ldots(1-R p 2)
$$

where $\mathrm{Rx} 12, \mathrm{R} 22$ is the $\mathrm{R}$-square of the endogenous variable.

The magnitude of Q2 has a value with a range of $0<\mathrm{Q} 2<1$, where the closer to 1 , the better the model. The quantity of Q2 is equivalent to the coefficient of total determination in path analysis. The calculation of the goodness of fit model is as follows:

$$
\begin{aligned}
\mathrm{Q}^{2} & =1-(1-R 12)(1-R 22) \\
& =1-(1-0.328)(1-0.699) \\
& =1-(0.10)(0.48) \\
& =1-0.048 \\
& =0.95
\end{aligned}
$$


Based on the calculation above, 95 percent relate the productivity variable which is explained by the variables of employee motivation and discipline while the remaining 5 percent is explained by variables that are not included in the model.

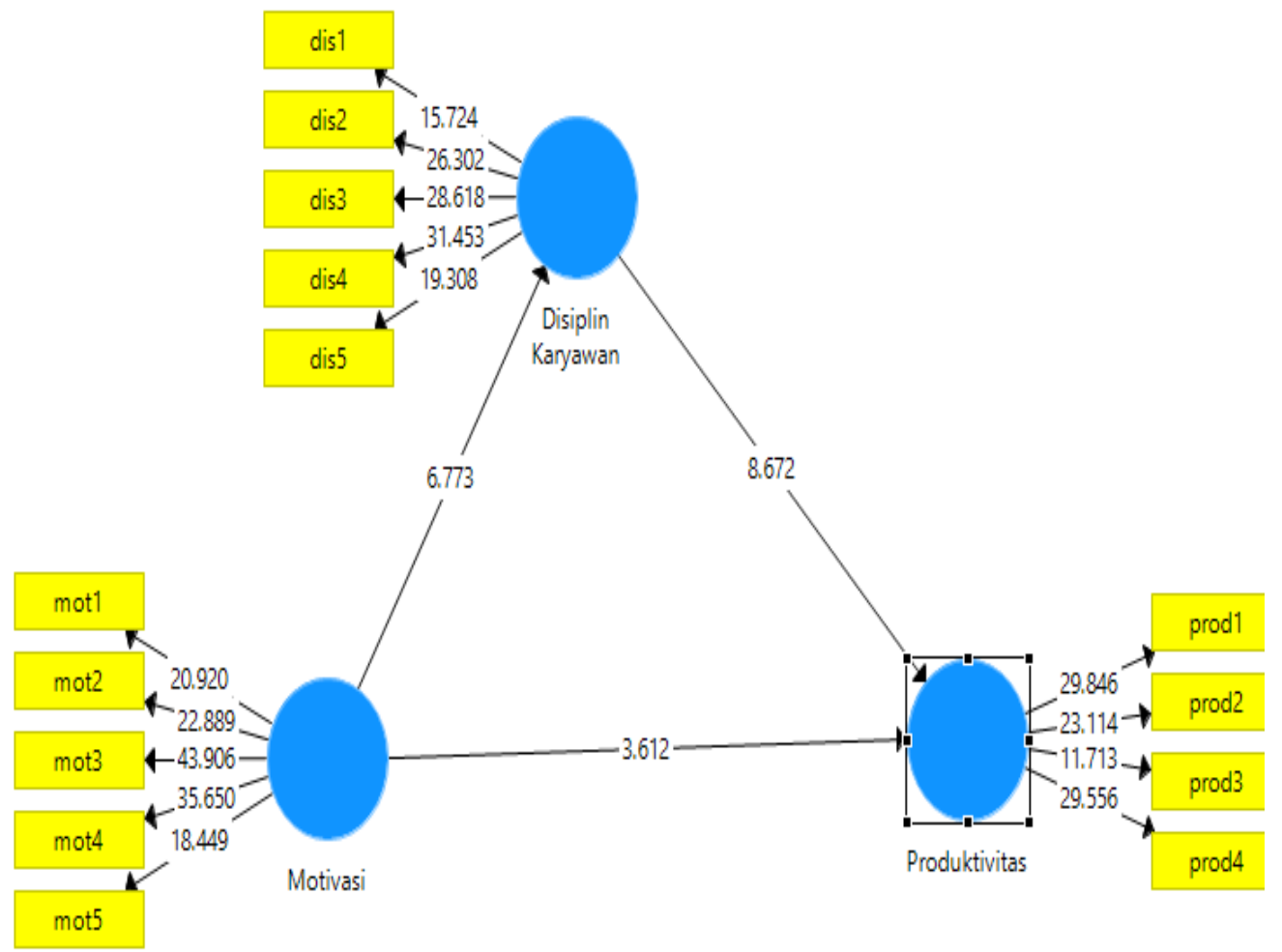

Figure 2. Path diagram of hypothesis test results

Source: Data processed by researchers, 2019

This structural model is called a reflexive model where the covariance of indicator measurements is influenced by latent constructs or reflects variations from unidimensional constructs which is represented by an ellipse with several arrows from the construct to the indicator (Astiti \& Surya, 2020). This model hypothesizes that changes in latent constructs will affect changes in indicators. In this model, there is one exogenous variable, namely the motivation variable, and two variables endogenous variables, namely employee discipline and productivity. The three variables have their respective indicators.

\section{Hypothesis test}

The path coefficients of the effect of motivation on employee discipline, the effect of employee discipline on productivity, and the effect of motivation on productivity are presented in Table 5.

Table 5

Result for Inner model

\begin{tabular}{lcccc}
\hline \multicolumn{1}{c}{ Influence } & $\begin{array}{c}\text { Original } \\
\text { Sample } \\
(\mathrm{O})\end{array}$ & $\begin{array}{c}\text { Standard } \\
\text { Deviation } \\
(\text { STDEV })\end{array}$ & $\begin{array}{c}\text { T Statistics } \\
(\mid \text { O/STERR } \mid)\end{array}$ & P Values \\
\hline $\begin{array}{l}\text { Employee Discipline } \square \\
\text { Productivity }\end{array}$ & 0.621 & 0.070 & 8.875 & 0.000 \\
$\begin{array}{l}\text { Motivation } \square \text { Employee Discipline } \\
\text { Motivation } \square \text { Productivity }\end{array}$ & 0.573 & 0.087 & 6.615 & 0.000 \\
\hline
\end{tabular}

Pemayun, C. I. B., \& Martini, I. A. O. (2021). Implementation motivation, work discipline in work productivity of employees in the hospital. International Research Journal of Management, IT and Social Sciences, 8(6), 630-638. https://doi.org/10.21744/irjmis.v8n6.1961 
Source: data processed by researchers, 2019

In this study, the $\mathrm{T}$-table value with a significance of $5 \%, \mathrm{dk}=92$, is 1,980 as set out in Appendix 5. Taking into account the path coefficient in Table 4.5, it turns out that the $\mathrm{t}$ statistic value is above 1,980, it can be stated that it has an influence on employee discipline on productivity. with a path coefficient value of 0.621 and a t statistic value of 8.875 which is greater than 1.980 . This means that there is a significant positive effect of employee discipline on the productivity of 0.621 . The effect of motivation on employee discipline with a path coefficient value of 0.573 and a tstatistic value of 6.615 which is greater than 1.980. This means that there is a significant positive effect of motivation on employee discipline of 0.621 . The effect of motivation on productivity with a path coefficient value of 0,307 and the $t$ statistic value of 3.730 is greater than 1.980 . This means that there is a significant positive effect of motivation on the productivity of 0.307 .

The results of testing the first hypothesis show that the influence of motivation on employee discipline shows a path coefficient value of 0.573 with a t-statistic value of 6.615 . The t-statistical value is greater than the t-table value of 1.980 which indicates that there is a positive and significant effect of the motivation variable on employee discipline at Udayana University Hospital Bali. The path coefficient shows that motivation has a positive influence on employee discipline.

Based on the results of hypothesis testing which states that there is a positive and significant influence of motivation on employee discipline, where employee motivation increases significantly, it can be seen from the achievement of physiological needs, security needs, social needs, self-esteem needs, and self-actualization needs so that they can have self-awareness of employees. to always be present on time, work obediently or following the time or working hours provisions, have work skills on their duties, have a good attitude, and are always creative, innovative in their work to improve employee discipline. The results of the study are in line with the research presented Nurwidyanti \& Marnis (2015).

The results of testing the second hypothesis indicate that there is an influence of motivational variables on productivity with a path coefficient value of 0.307 with a t-statistic value of 3.730 . The $t$-statistic value is greater than the t-table value of 1.980 indicating that there is a positive and significant effect of the motivation variable on productivity. The path coefficient shows that motivation has a positive effect on productivity so that the hypothesis is tested.

Based on the results of hypothesis testing which states that there is a positive and significant influence of motivation on employee discipline, where employee motivation increases significantly, it can be seen from the achievement of physiological needs, security needs, social needs, self-esteem needs, and self-actualization needs so that they can work optimally on their abilities. employee work, work results achieved are in line with expectations, have work spirit and have a spirit of self-development, quality, efficiency to increase productivity. The research was conducted by Assagaf \& Dotulong (2015), according to the results of this study.

The path coefficient of the influence of employee discipline on productivity is 0.621 with a t-statistic value of 8.875. The $t$-statistic value is greater than the $t$-table value of 1.980 indicating that there is a positive and significant effect of the employee discipline variable on productivity. The path coefficient shows that employee discipline has a positive influence on productivity, meaning that the employee discipline variable can provide changes to productivity variables at Udayana University Hospital Bali.

Based on the results of hypothesis testing which states that there is a positive and significant effect of employee discipline on productivity, where employee discipline increases significantly, it can be seen from always being on time, always obeying the provisions of working hours, having work skills in their field of work, having a good attitude and always creative, innovative in work so that they can work optimally on the workability of employees, the work results achieved are following expectations, have work spirit and have a spirit of self-development, quality, efficiency to increase productivity. The results of this study are the following research conducted by Assagaf \& Dotulong (2015) and Dunggio (2013).

\section{Conclusion}

Based on the results of the analysis and discussion, it can be concluded as follows:

a) The effect of motivation on employee discipline shows the path coefficient value of 0.573 with a t-statistic value of 6.615 . The $t$-statistic value is greater than the t-table value of 1.980 which indicates that there is a 
positive and significant effect of the motivation variable on employee discipline at Udayana University Hospital Bali. The path coefficients show that motivation has a significantly positive effect on employee discipline.

b) The influence of motivational variables on productivity with a path coefficient value of 0.307 with a t-statistic value of 3.730. The t-statistic value is greater than the t-table value of 1.980 indicating that there is a positive and significant effect of the motivation variable on productivity. The path coefficients show that motivation has a significant positive effect on productivity.

c) The effect of employee discipline on productivity is 0.621 with a t-statistic value of 8.875 . The t-statistic value is greater than the t-table value of 1.980 indicating that there is a positive and significant effect of the employee discipline variable on productivity. The path coefficient shows that employee discipline has a positive effect on productivity, meaning that the employee discipline variable can provide changes to the productivity variable at Udayana University Hospital Bali.

Conflict of interest statement

The authors declared that they have no competing interests.

Statement of authorship

The authors have a responsibility for the conception and design of the study. The authors have approved the final article.

Acknowledgments

We are grateful to two anonymous reviewers for their valuable comments on the earlier version of this paper.

Pemayun, C. I. B., \& Martini, I. A. O. (2021). Implementation motivation, work discipline in work productivity of employees in the hospital. International Research Journal of Management, IT and Social Sciences, 8(6), 630-638. https://doi.org/10.21744/irjmis.v8n6.1961 


\section{References}

Anggorowati, M. D. (2012). Pengaruh Motivasi Terhadap Disiplin Dan Kinerja Perawat Bagian Anak Dan Bedah.

Ardana, I. K., Mujiati, N. I., \& Utama, I. W. M. U. (2012). Manajemen sumber daya manusia.

Arisandy, D. (2004). Hubungan antara persepsi karyawan terhadap disiplin kerja karyawan bagian produksi pabrik keramik "ken lila production" di jakarta. Jurnal Psyche, 1(2), 23-34.

Armstrong, M. (2010). Armstrong's essential human resource management practice: A guide to people management.

Arshadi, N. (2010). Basic need satisfaction, work motivation, and job performance in an industrial company in Iran. Procedia-Social and Behavioral Sciences, 5, 1267-1272. https://doi.org/10.1016/j.sbspro.2010.07.273

Assagaf, S. C. Y., \& Dotulong, L. O. (2015). Pengaruh Disiplin, motivasi dan semangat kerja terhadap produktivitas kerja pegawai dinas pendapatan daerah kota manado. Jurnal EMBA: Jurnal Riset Ekonomi, Manajemen, Bisnis dan Akuntansi, 3(2).

Astiti, M. W., \& Surya, I. B. K. (2020). The role of organizational commitments in mediating the effect of work motivation and job satisfaction towards turnover intention on nurses private hospital. International Research Journal of Management, IT and Social Sciences, 8(1), 25-34. https://doi.org/10.21744/irjmis.v8n1.1101

Bangun, W. (2012). Manajemen Sumber Daya Manusia. Jakarta: Erlangga. Internatinal Journal, 4.

Dunggio, M. (2013). Semangat dan disiplin kerja terhadap produktivitas kerja karyawan pada PT. Jasa Raharja (persero) cabang Sulawesi Utara. Jurnal EMBA: Jurnal Riset Ekonomi, Manajemen, Bisnis dan Akuntansi, 1(4).

Dwivedula, R., \& Bredillet, C. N. (2010). Profiling work motivation of project workers. International Journal of Project Management, 28(2), 158-165. https://doi.org/10.1016/j.ijproman.2009.09.001

Farida, L., \& Christian, F. A. (2016). Pengaruh Disiplin Kerja terhadap Produktivitas Kerja Karyawan Bagian Produksi Pabrik Kelapa Sawit (Pks) PT. Perkebunan Nusantara V Sei Rokan Kec. Pagaran Tapah Darussalam Kab. Rokan Hulu (Doctoral dissertation, Riau University).

George, J. M., Jones, G. R., \& Sharbrough, W. C. (2005). Understanding and managing organizational behavior. Upper Saddle River, NJ: Pearson Prentice Hall.

Ghozali, I. (2006). Aplikasi analisis multivariate dengan program SPSS.

Göbel, C., \& Zwick, T. (2013). Are personnel measures effective in increasing productivity of old workers?. Labour Economics, 22, 80-93. https://doi.org/10.1016/j.labeco.2012.11.005

Harlie, M. (2012). Pengaruh Disiplin Kerja, Motivasi dan Pengembangan Karier terhadap Kinerja Pegawai Negeri Sipil pada Pemerintah Kabupaten Tabalong di Tanjung Kalimantan Selatan. Jurnal Aplikasi Manajemen, 10(4), 860-867.

Hasibuan, M. (2011). Manajemen Sumber dan Daya Manusia Edisi Revisi. Jakarta: Bumi Aksara.

$\mathrm{Hu}$, Y., \& Liu, L. (2020). Becoming industrious female citizens: Work, discipline, and negotiation in Chinese female prison. International Journal of Law, Crime and Justice, 63, 100420. https://doi.org/10.1016/j.ijlcj.2020.100420

Lam, C. F., \& Gurland, S. T. (2008). Self-determined work motivation predicts job outcomes, but what predicts selfdetermined work motivation?. Journal of research in personality, 42(4), 1109-1115. https://doi.org/10.1016/j.jrp.2008.02.002

Miftah, T. (2012). Perilaku Organisasi Konsep Dasar Dan Implikasinya, Jakarta: PT. Raja Grafindo Persada.

Nitisemito, A. S. (2006). Manajemen Personalia, edisi kedua. Jakarta: Ghalia Indonesia.

Nnoaham, K. E., Hummelshoj, L., Webster, P., d'Hooghe, T., de Cicco Nardone, F., de Cicco Nardone, C., ... \& Study, W. E. R. F. G. (2011). Impact of endometriosis on quality of life and work productivity: a multicenter study across ten countries. Fertility and sterility, 96(2), 366-373. https://doi.org/10.1016/j.fertnstert.2011.05.090

Nurcahya, E. (2007). Configuration instead of new design using reference product structures. In The Future of Product Development (pp. 125-134). Springer, Berlin, Heidelberg.

Nurwidyanti, F., \& Marnis, M. (2015). Pengaruh pengawasan dan iklim organisasi terhadap motivasi dan disiplin kerja pegawai pada kantor biro umum sekretariat daerah provinsi Riau. Jurnal Tepak Manajemen Bisnis, 7(3).

Paré, P., Gray, J., Lam, S., Balshaw, R., Khorasheh, S., Barbeau, M., ... \& McBurney, C. R. (2006). Health-related quality of life, work productivity, and health care resource utilization of subjects with irritable bowel syndrome: baseline results from LOGIC (Longitudinal Outcomes Study of Gastrointestinal Symptoms in Canada), a naturalistic study. Clinical therapeutics, 28(10), 1726-1735.https://doi.org/10.1016/j.clinthera.2006.10.010

Putra, A. K. (2013). Pengaruh motivasi intrinsik dan motivasi ekstrinsik terhadap kepuasan kerja. Jurnal Ilmu Manajemen (JIM), 1(1).

Rawung, F. H. (2013). The effect of leadership on the work motivation of higher education administration employees (Study at Manado State University). IOSR Journal of Business and Management, 15(1), 28-33. 
Rivai, V. (2009). Pengaruh disiplin kerja terhadap kinerja pegawai kantor departemen sosial kabupaten gorontalo. Gorontalo: Universitas Ichsan Gorontalo.

Sedarmayanti, S., \& Rahadian, N. (2018). Hubungan Budaya Kerja dan Lingkungan Kerja Terhadap Peningkatan Kinerja Pegawai Pada Lembaga Pendidikan Tinggi. Jurnal Ilmu Administrasi: Media Pengembangan Ilmu dan Praktek Administrasi, 15(1), 63-77.

Simon, G. E., Revicki, D., Heiligenstein, J., Grothaus, L., VonKorff, M., Katon, W. J., \& Hylan, T. R. (2000). Recovery from depression, work productivity, and health care costs among primary care patients. General hospital psychiatry, 22(3), 153-162. https://doi.org/10.1016/S0163-8343(00)00072-4

Stoeber, J., Davis, C. R., \& Townley, J. (2013). Perfectionism and workaholism in employees: The role of work motivation. Personality and Individual Differences, 55(7), 733-738. https://doi.org/10.1016/j.paid.2013.06.001

Triasmoro, D. (2012). Pengaruh Kemampuan, Motivasi Dan Kinerja pegawai Terhadap Produktifitas Kerja (Studi Kasusdi Bappeda Kabupaten Kediri).

Uchino, M., Uchino, Y., Dogru, M., Kawashima, M., Yokoi, N., Komuro, A., ... \& Tsubota, K. (2014). Dry eye disease and work productivity loss in visual display users: the Osaka study. American journal of ophthalmology, 157(2), 294-300. https://doi.org/10.1016/j.ajo.2013.10.014

Widana, I. W., Suarta, I. M., \& Citrawan, I. W. (2019). Work motivation and creativity on teacher ability to develop HOTS-based assessments. International Journal of Social Sciences and Humanities, 3(3), 188-200. https://doi.org/10.29332/ijssh.v3n3.378

Pemayun, C. I. B., \& Martini, I. A. O. (2021). Implementation motivation, work discipline in work productivity of employees in the hospital. International Research Journal of Management, IT and Social Sciences, 8(6), 630-638. https://doi.org/10.21744/irjmis.v8n6.1961 